\title{
NOTES ON HETEROONOPS AND TRIAERIS
}

\author{
(ARANEAE; OONOPIDAE) \\ By Arthur M. Chickering \\ Museum of Comparative Zoology
}

In this short note are some additions and corrections to my previously published revisions.

\section{Heteroonops spinimanus (Simon) \\ Figures $\mathrm{I}-4$}

Oonops spinimanus Simon, 1891: 563, fig. 6. The female holotype from St. Vincent, B. W. I. is in the British Museum (Natural History). Simon, 1892: 445; 1893: 294; Petrunkevitch, 1911: 128; 1929: 67, figs. 53-57; Gertsch, 1936: 8 .

Heteroonops spinimanus, - Dalmas, 1916: 203, 217; Bryant, 1940: 205; Roewer, 1942: 276; Bonnet, 1957: 2185; Chickering, 1969: 154, figs. 28-32.

I have been much interested in Heteroonops spinimanus (Simon) for many years. Simon ( I89I) described the species from females collected on St. Vincent, B. W. I. In 1892 he reported the species from Venezuela. Dr. Petrunkevitch; in his study of Puerto Rican spiders, (1929), stated that he had males and females for study in the collection of the American Museum of Natural History. These were collected in 1915 in San Juan, Cayey, Naranjito and Coamo Springs. He regarded the males, taken in these localities, as belonging with the females and described a male from San Juan as the male of Oonops spinimanus Simon. This identification has been widely accepted up to the present time. I have had the specimens that were apparently studied by Dr. Petrunkevitch also on loan from the American Museum of Natural History. It has been very disappointing to find almost all of the specimens, believed to be those studied by Dr. Petrunkevitch, in a very dismembered and almost useless condition. I think there is no question about the status of the females involved but I am obliged to regard the identification of the males as open to serious doubts. Dr. Petrunkevitch noted a considerable degree of variation among the males in respect to the appearance of the palpal conductor and embolus, indicating, perhaps, a mixture of species. I have spent much time in searching through my extensive collection of Oonops for males which could be matched with the well established females but without success. I am of the opinion that the males identified as Oonops spinimanus Simon by 

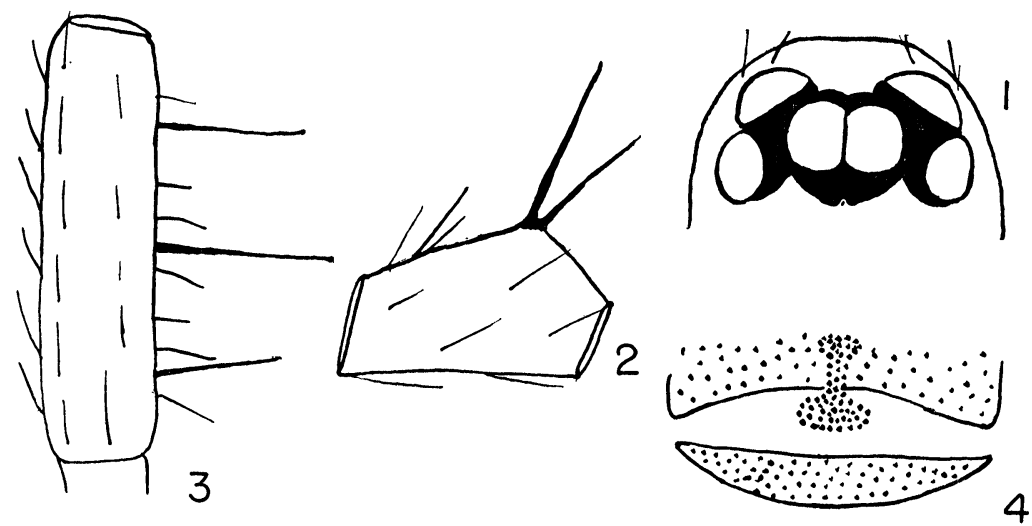

Figures 1-4. Heteroonops spinimanus (Simon). Fig. 1. Eyes of female from above. Fig. 2. Right palpal patella; nearly dorsal view. Fig. 3. Right palpal femur; retrolateral view. Fig. 4. Epigynal area of female from St. Vincent; viewed from below.

Dr. Petrunkevitch really belong with Oonops castellus Chickering, now believed to be rather widely distributed among the West Indies. I readily concede, however, that there is no certainty at the present time.

Records. In addition to the records cited above the following should now be added in order to bring the record up to date: Dr. Gertsch recognized the species from Florida in 1936, where it is now known to be fairly common (Chickering, 1969). Miss Bryant ( 1940 ) reported the finding of females in Cuba. I have taken many females in the following localities during my collecting trips in 1954, 1957-1958, 1963-1964, 1965 and 1966: Jamaica, W. I. where the species seems to be abundant; St. Thomas, St. John and St. Croix, U. S. Virgin Islands; Puerto Rico, W. I.; St. Lucia, St. Kitts, Nevis and St. Vincent, all in the British West Indies; Trinidad, W. I.; Panama Canal Zone and parts of Panama, particularly in the mountainous regions; and finally in Costa Rica.

\section{Triaeris pusillus (Bryant), new combination}

Hytanis pusilla Bryant, 1942: 326, figs. 13-14. The female holotype from St. Croix, V. I. is in the Museum of Comparative Zoology, examined. Triaeris reticulatus Chickering, 1968: 354, figs. 6-13. The male holotype from St. Croix, V. I. is in the Museum of Comparative Zoology. NEW SYNONYMY. 
The female, regarded by Miss Bryant as representing a new species of Hytanis, was completely overlooked during my study of the genus Triaeris (1968). At that time I believed that I had a new species of the genus represented by a male from St. Croix, V. I. Because of the close similarity of structure and coloration, I believed that a female from Nevis, B. W. I., belonged with the male from St. Croix, V. I. As a result of my examination of the holotype of Hytanis pusilla Bryant I think it is logical to believe that this female belongs with my male from the same locality and that it represents a species of Triaeris. This leaves the status of the female from Nevis in some doubt. This species may be a new one but I am not yet certain about this. Further careful collecting among the numerous West Indian Islands is obviously needed.

\section{ReFERENCES}

\section{Bonnet, Pierre}

1957. Bibliographia Araneorum. Toulouse. 2(3).

Bryant, Elizabeth

1940. Cuban Spiders in the Museum of Comparative Zoology. Bull. Mus. Comp. Zool. 86(7) : 249-532, 22 pls.

1942. Notes on the spiders of the Virgin Islands. Bull. Mus. Comp. Zool., 89: 317-363.

Chickering, A. M.

1968. The Genus Triaeris Simon (Araneae, Oonopidae) in Central America and the West Indies. Psyche, 75(1): 351-359.

1969. The Family Oonopidae (Araneae) in Florida. Psyche, 76: 144162,41 figs.

Dalmas, Compte de

1916. Revision du Genre Orchestina E. Simon. Ann. Soc. Entom. France, 85: 203-258, 30 figs.

GeRTSCH, W. J.

1936. Further Diagnoses of New American Spiders. Amer. Mus. Novitates, No. 852: 1-27, 4 pls.

Petrunkevitch, Alexander

1911. A synonymic index-catalogue of spiders of North, Central, South America, etc. Bull. Amer. Mus. Natur. Hist., 29: 1-809.

1929. The spiders of Porto Rico. Pt. 1. Trans. Connecticut Acad. Arts and Sci. 30:7-158, 150 figs.

Roewer, C. Fr.

1942. Katalog der Araneae. 1: 1-1040.

SiMON, E.

1891. On the spiders of the island of St. Vincent. Pt. 1 Proc. Zool. Soc. of London, Nov. 17, 1891: 549-575.

1892. Voyage de M. E. Simon au Venezuela. Ann. Soc. Entom. France, 61: 423-462, $1 \mathrm{pl}$.

1892-1895. Histoire naturelle des Araignées. Deuxième Edition. 1 Librairie Encyclopedique de Roret, Paris. 

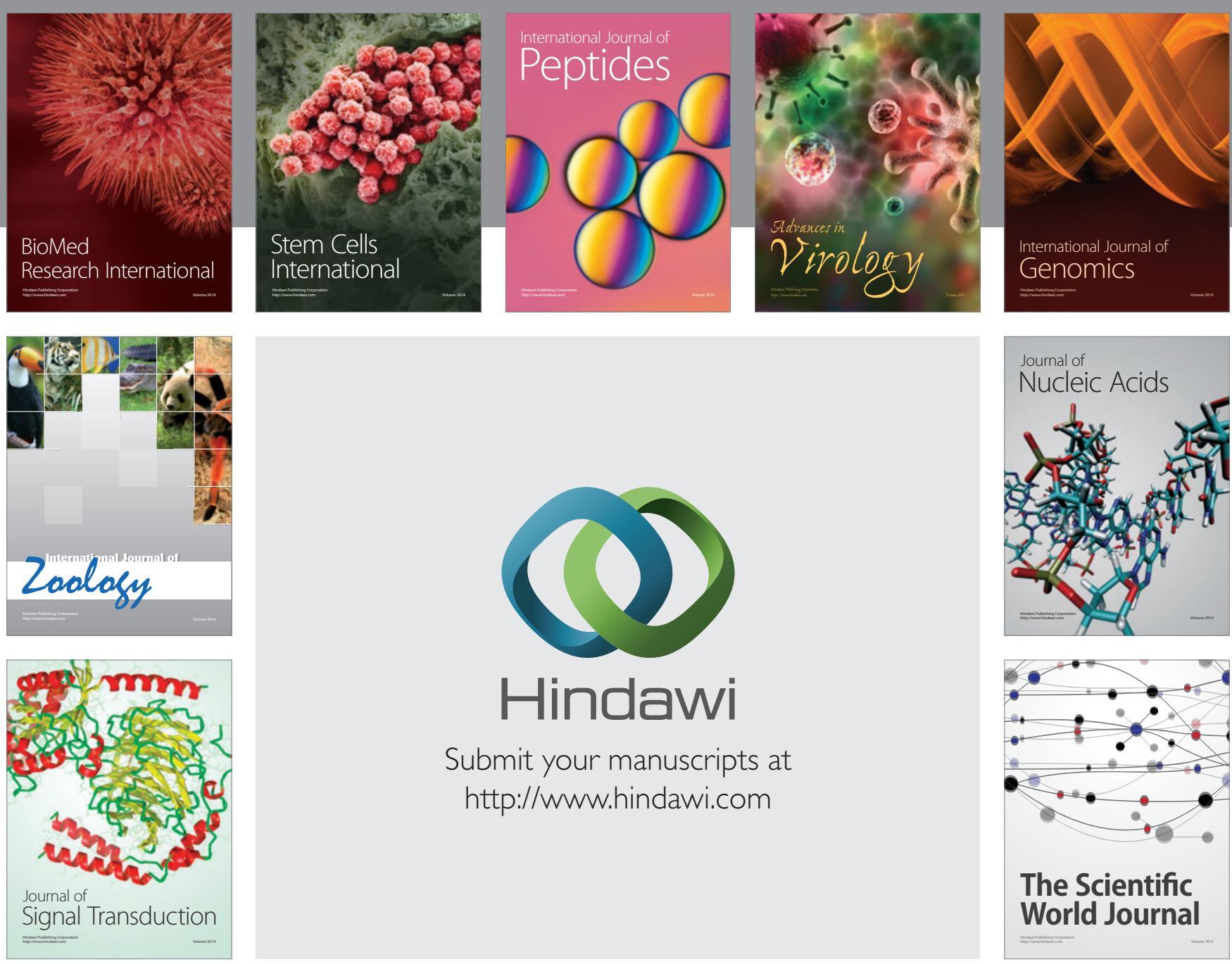

Submit your manuscripts at

http://www.hindawi.com
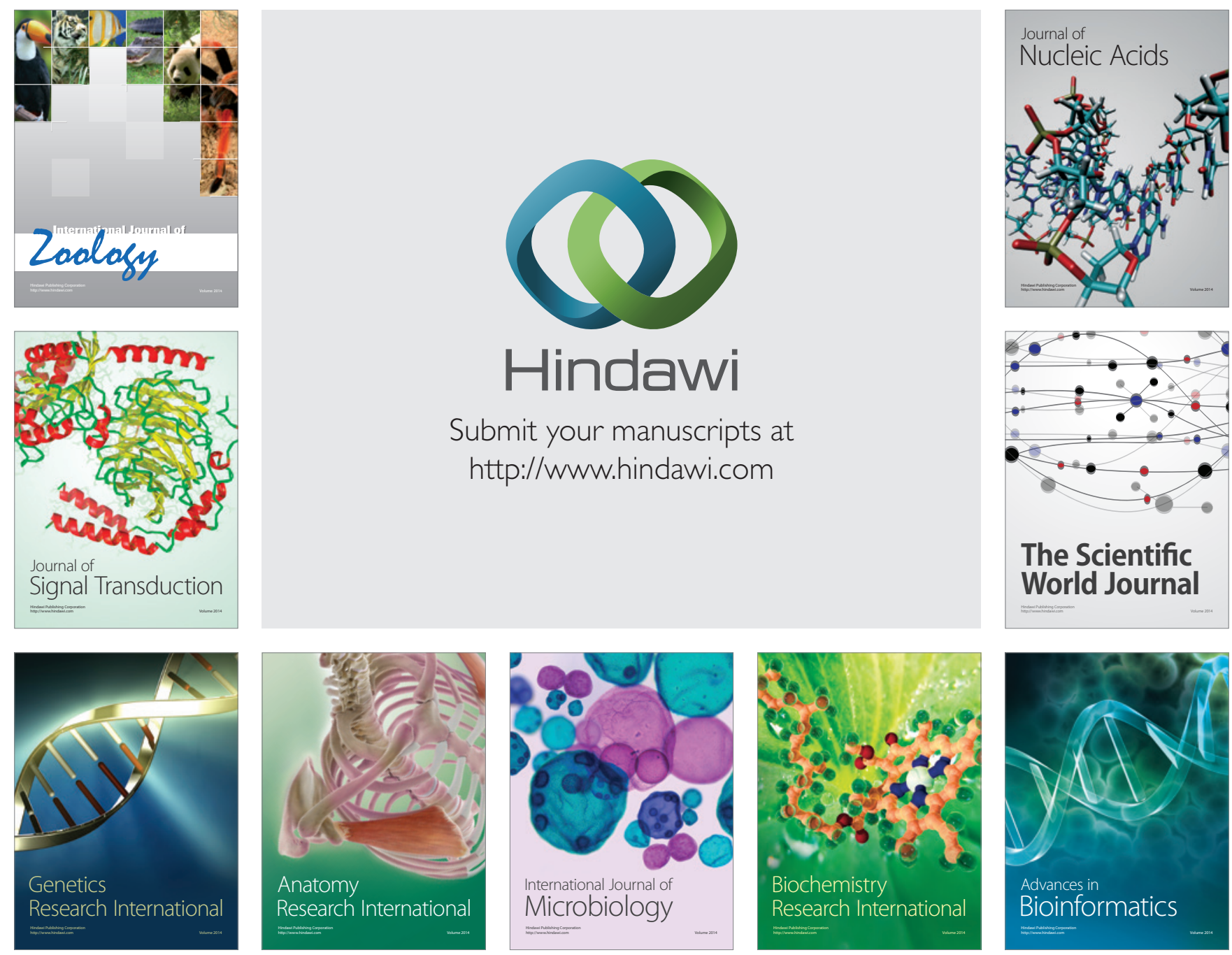

The Scientific World Journal
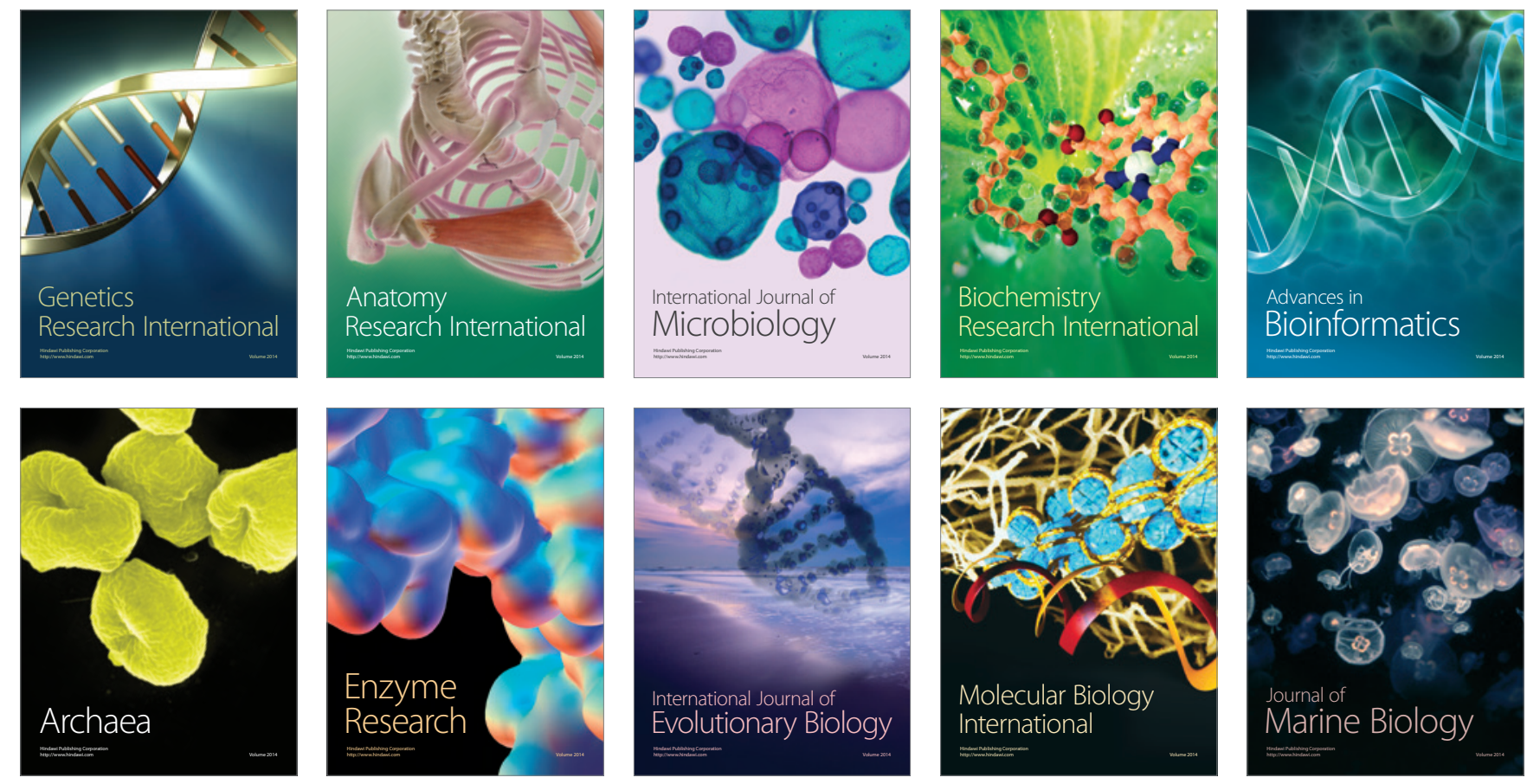